\title{
MEMAKNAI PERANG BARATAYUDHA DALAM PERSPEKTIF KITAB KELUARAN (EXODUS)
}

\author{
Wiwid Widyaswoko \\ Sekolah Tinggi Theologia Abdiel \\ wiwid.kpg@gmail.com
}

\begin{abstract}
This article discusses and compares between the story of the war of Baratayudha and that of the Exodus in the Old Testament. The writer tries to give meaning about the war of Baratayudha from the perspective of the theology of the war from the Exodus. In the Exodus, God have always defended the oppressed people when war happened. God was with the oppressed people and He gave freedom to them. In the war, God did not only have aim to show His power but to destroy the evil.

Keywords: Barathayuda, Exodus (Kitab Keluaran), perang, penindasan, pembebasan
\end{abstract}

\section{Pendahuluan}

Enjing bidal gumuruh

Saking jroning praja

Gunging kang bala kuswa

Aba busananira lir surya wedalira

Saking jaladri arsa madangi jagad

Duk mungup-mungup aneng

Sakpucuking wukir

Mrababak bang sumirat

Keneng soroting surya

Mega lan gunung-gungung

Terjemahan:

Pagi berangkat gegap gempita dari ibukota negara

Segenap bala tentara dengan kebesaran busana seragam

Ibarat matahari terbit dari tepi samudra

Bergerak menerangi alam raya

Gemerlap sinarnya menyinari Pucuk gungung-gungun dan awan-awan

Tampak kemerah-merahan demikian pula pantulan cahaya

Dari mega dan gungung-gungung. 
Demikian salah satu suluk ${ }^{1}$ dalam pewayangan yang disebut Suluk Budhalan. Suluk ini biasa dinyanyikan ketika prajurit hendak maju kemedan laga. Suluk Budhalan di atas banyak mengungkapkan estetika keprajuritan. ${ }^{2}$ Setelah Suluk Budhalan, keluarnya prajurit bisa diiringi instrumen gamelan yang berirama cepat dan semangat, yang mengisahkan majunya barisan prajurit tersebut, misalnya Lancaran Gambuh atau Lancaran Singo Nebak.

Perang menjadi bagian dalam masyarakat Jawa, dan hal ini dapat kita lihat dalam berbagai kesenian masyarakat Jawa yang mencerminkan peperangan. Dalam pewayangan, perang merupakan bagian yang selalu ada dalam setiap pementasan, perang dalam dunia pewayangan biasanya merupakan suatu penggambaran pertarungan dualisme, pertarungan antara yang baik dan yang jahat. ${ }^{3}$ Meskipun dalam lakon tertentu tokoh baik harus mengecap kekalahan (misalnya dalam Pandhawa Dadhu) namun pada akhirnya yang baik akan selalu memenangkan pertandingan.

Ada empat perang besar dalam dunia pewayangan. Perang yang pertama adalah perang besar Prabu Hastina Pandu dengan raja dari Pringgondani Prabu Tremboko disebut dengan perang Pamoksa. Kedua adalah perang Guntarayana, peperangan antara Begawan Wiptaning melawan Niwatakawaca. Ketiga adalah perang Gojali Suta, peperangan antara Boma Narakasura dan Sri Kresna dan yang keempat adalah perang Baratayuda di padang Kurusetra, perang besar antara Pandawa dan Kurawa, negara Astina melawan Amarta. Baratayuda merupakan perang yang besar, banjir darah terjadi ketika perang besar itu, sampai-sampai Prabu Baladewa yang sedang bertapa di bawah air terjun terbangun dari pertapaannya karena air yang menjadi darah. Baratayuda merupakan perang yang sudah ditakdirkan oleh para dewa. Dewapun banyak berintervensi baik dalam perang maupun sebelum perang, agaknya para dewa di kayangan memang memihak pada para Pandawa. Salah satunya adalah keberpihakan Sri Bathara Kresna sebagai dewa Wisnu yang menjelma dalam diri ratu Dwarawati.

Intervensi Dewa sangat perpengaruh dalam peperangan Pandawa melawan Kurawa, hal yang sama sebenarnya kita lihat dalam kehidupan bangsa Israel. Tuhan adalah Ilahi

\footnotetext{
${ }^{1}$ Suluk merupakan lagu vokal yang dilantunkan oleh dalang untuk memberikan suasana tertentu dalam adegan-adegan pertunjukan wayang.

${ }^{2}$ Purwadi, Falsafah Militer Jawa. Praktik kemiliteran ala kerajaan-kerajaan Jawa (Bantul: Aksara, 2015), 151.

${ }^{3}$ Sebagai contoh peperangan antara Janaka dan Buto Cakil, Pandawa dan Kurawa, Pandudewanata dan Prabu Trembaka dlsb. Namun ada juga peperangan yang tidak menonjolkan sisi dualisme. Misaln ya dalam lakon Karna Tanding, Prabu Karna berperang demi mempertahankan dan melakukan amalannya sebagai seorang kesatria. Demikian juga dengan peperangan antar Kumbakarna dengan Kera dari pasukan Hanoman. Kumbakarna sama sekali tidak membela sang kakak Prabu Rahwana yang nyata-nyata telah melakukan kesalahan. Namun dia ikut berperang karena membela negaranya Ngalengka Diraja. Cerita keduanya diabadikan dalam serat Tripama.
} 
yang turut berintervensi untuk membela bangsa Israel. Israel mengimani bahwa Tuhanpun ikut berperang bagi mereka, oleh sebab itu salah satu terminologi untuk Tuhan adalah Tuhan Pahlawan perang. Tuhan menentukan keberpihakannya kepada Israel, namun bukan berarti bahwa dalam setiap pertempuran Israel menuai kemenangan. Karena hal-hal tertentu, Tuhanpun sepertinya tidak berpihak kepada Israel. Dua kisah ini memaparkan nilai-nilai etis peperangan, nilai-nilai politik dan keberpihakan Ilahi dalam peperangan.

\section{Bratayuda Jayabinangun, ${ }^{4}$ Narasi Singkat}

Baratayuda merupakan lakon pewayangan yang terkenal dan familier dalam masyarakat. Baratayuda sendiri merupakan sebuah lakon gubahan Empu Sedah (dan Empu Panuluh sebagai penerus penulis Baratayuda) pada tahun 1079 dibawah perintah oleh raja Jayabaya. ${ }^{5}$ Kakawin/ serat Baratayuda ini merupakan penggambaran peperangan saudara antara Kerajaan Kediri dan Kerajaan Jenggala. ${ }^{6}$

Lakon ini menjadi istimewa karena dianggap memiliki nilai sakral, sehingga lakon ini tidak boleh dimainkan pada sembarang tempat dan sembarang waktu. ${ }^{7}$ Sehingga muncul kepercayaan bahwa jika tempat dan waktu yang tidak sesuai maka akan menimbulkan bencana. Baratayuda sendiri merupakan salah satu lakon atau kisah yang cukup panjang yang dibagi ke dalam 11 adegan atau lakon: Lakon Kresno Duta, Lakon Jabelan, lakon Kresna Gugah, Lakon Bisma Gugur, Lakon Angkawijaya Gugur, Lakon Jayadrata Gugur, Lakon Pejahipun Gatotkaca, Lakon Pejahipun Adipati Karno, Pejahipun Suyudana dan Parikesit Lahir. ${ }^{8}$

Seperti namanya, Baratayuda berarti peperangan antara trah Barata, ${ }^{9}$ alias perang antar keluarga keturunan Resi Wiyasa Kresna Dwipaya. Peperangan ini berakar pada konflik kekuasaan kerajaan Ngastina Pura. Resi Wiyasa memiliki tiga orang putra, ketiganya adalah Destrarastra yang terlahir buta, Pandu Dewanata dan Arya Yamawidura. Ketika Prabu Wiyasa lengser keprabon, yang memiliki hak kerajaan adalah Destrarata si sulung. Namun Destrarastra merelakan kerajaan Ngastina dipimpin oleh Pandu dan anak

\footnotetext{
${ }^{4}$ Kisah ini memiliki banyak versi. Dalam makalah ini yang akan dibahas adalah Baratayuda versi pewayangan jawa versi Surakatra. 9.

${ }^{5}$ Karel Fredrik Winter, Serat Bratayuda (Jakarta: Departemen Pendidikan dan kebudayaan, 1980),

${ }^{6}$ Purwadi, Seni Pedhalangan Wayang Purwa (Jakarta, 2017), 184. http://staf.uny.ac.id (diakses pada 5 April 2018).

${ }^{7}$ Endah Budiarti, “Lakon Baratayuda Versi Klaten: Kajian Struktur Naratif”. Resital: Jurnal Seni Pertunjukan 13, no. 2 (Desember 2012): 166.

${ }^{8}$ Ibid 166-167. 2018)

${ }^{9} \mathrm{http} / /$ :www.scribd.com/doc/191779538/baratayuda-perangmenuai-karma (diakses 15 April
} 
cucunya, karena dia menyadari bahwa dia buta. Akhirnya Pandu Dewanatalah yang menjadi raja atas Ngastina. Sayangnya peperangan dengan Prabu Trembaka raja Pringgondani merengut nyawa sang prabu. Kepergianya meninggalkan Pandwa yang kala itu masih sangat muda. Ngastina—berkat akal Sengkuni—kini menjadi milik Destrarastra, dengan perjanjian bahwa kelak ketika Pandawa telah dewasa, kerajaan itu akan dikembalikan kepada mereka, namun Destrarastra tidak menepati hal itu, dia justru mewariskan kerajaan itu kepada Duryudana.

Pandawa beserta ibu-ibunya diusir dari Ngastina, dan mereka mendirikan kerajaan sendiri hasil membuka hutan Wisamerta yang kemudian dinamakan Indraprasta atau Amarta. ${ }^{10}$ Indraprasta merupakan negara yang indah ${ }^{11}$ panjang punjung pasir wukir, gemah ripah loh jinawi demikian sering disebutkan untuk menggambarkan keindahan negara Amarta. Hal ini membuat kecemburuan dari pihak Kurawa. Atas pemikian dari patih Sengkuni, maka diadakan judi dadu. Sengkuni tahu bahwa Puntadewa adalah seorang yang tidak bisa berkata tidak ${ }^{12}$. Taruhan dari judi dadu adalah negara berserta isinya. Singkat cerita Pandawa kalah dalam judi dadu tersebut, dan harus menjalani penghukuman yaitu pembuangan selama 12 tahun di hutan Kamyaka dan menjalani penyamaran selama setahun terakhir masa pembuangan. Jika diketahui oleh pihak Ngastina maka harus menjalani hukuman ulang. ${ }^{13}$

Setelah selesai masa pembuangan dan penyamaran, maka Pendawa hendak meminta kembali negara mereka Astina dari Prabu Duryudana. Dari negara Wirata, Puntadewa dan raja-raja koalisi yang lain sedang menyusun strategi peperangan. ${ }^{14}$ Kresna kemudian ditunjuk oleh Puntadewa sebagai duta utusan meminta bagian mereka ${ }^{15}$ dan jika bagian mereka tidak diberikan maka berarti Baratayuda akan terjadi demikian sebaliknya ${ }^{16}$. Namun demikian Prabu Duryudana tidak menepati janji mereka, dan demikian perang Baratayuda akan terjadi. ${ }^{17}$

Keberpihakan Raja Dwarawati, Prabu Sri Batara Kresna bukan tanpa alasan. Kejadian di Balekambang, ketika Prabu Kresna tidur dalam bertapa, dia sedang meraga sukma, rohnya sedang pergi ke khayangan untuk mencari keterangan isi kitab Jitapsara,

\footnotetext{
${ }^{10}$ Ibid., 4.

${ }^{11}$ Ibid., 4.

12 Ibid., 4.

${ }^{13}$ Ibid., 5 .

${ }^{14}$ Karel FrederikWinter. Serat Bratayuda, 9.

${ }^{15}$ Sebelumnya dewi Kunti dan Prabu Drupada juga diutus menjadi duta namun Astina tida juga diserahkan. Diutusnya Kresna sebagai duta dimainkan dalam lakon Kresna Duta.

${ }^{16}$ Purwadi, Serat Bharatayuda (Surakarta: Cendrawasih, 2014), 3.

${ }^{17}$ Ibid., 7.
} 
kitab yang berisi skenario perang Baratayuda. ${ }^{18}$ Sebelum bertapa dengan tidur, Kresna berpesan pada Setyaka dan Setyaki bahwa yang dilihatnya pertama kali sewaktu dia bangun dari tidurnya, dialah yang akan dibelanya saat perang nanti. Pihak Kurawa sudah mencoba membangunkannya, namun tidak bisa ${ }^{19}$ malahan cara mereka membangunkan Prabu Kresna menjadi gambaran bagaimana orang-orang ini akan meregang nyawa. Tanggap akan apa yang terjadi, Pandawa berhasil membangunkan sang Prabu Kresna dengan cara Janaka ikut meraga sukma menjemput sang Prabu. Benar saja sang prabu Krisna akhirnya bangun dari bertapanya, dan menyatakan kesanggupannya berpihak pada Pandawa saat Baratayuda. Sejalan dengan itu, para dewa di kayangan Jonggring Saloka juga berpihak pada pandawa dengan menuliskan jalannya perang dan memberikan kemenangan dipihak Pandawa. ${ }^{20}$

Setelah perundingan tidak mebuahkan hasil, maka genderang perangpun ditabuh, kedua pihak bersama dengan negara sekutunya memutuskan untuk berperang. Adalah tegal padang Kurusetra yang dijadikan tempat pertempuran besar itu terjadi. Selama 18 hari pertempuran itu terjadi dan memakan banyak korban dari kedua belah pihak. Anak-anak Werkudara harus meninggal dunia. Bahkan Antareja putra Wekudara harus merelakan dirinya mati sebelum Baratayuda. Hal ini terjadi atas andil Kresna agar Antareja tidak ikut bertanding dalam peperangan tersebut. Gatutkaca yang pada waktu itu menjadi senapati harus meninggal ditangan Adipati Karna yang memiliki senjata pengapesan pantangan dari Gatutkaca yaitu Kunta Wijawandanu. Abimanyu putra kesayangan Janaka juga meninggal, Begawan Bisma juga gugur ${ }^{21}$ dan belum lagi korban dari pihak koalisi kedua kerajaan dan korban dari prajurit rucah pasukan-pasukan kecil yang tidak terkira banyaknya. Dalam

${ }^{18}$ Ibid., 9.

${ }^{19}$ Ibid., 10. Cara mereka membangunkan prabu Kresna merupakan sasmita atau tanda bagaimana mereka akan meninggal waktu Baratayuda. Prabu Karna membangunkan Prabu Kresna dengan meraba leher sang Prabu, hal ini menjadi tanda bahwa Prabu Karna akan meninggal dengan leher terpenggal. Arya Dursasana membangunkan Prabu Kresna dengan menggoyang-goyangkan tubuhnya, hal ini menandakan bawa tubuhnya akan terpotong-potong waktu perang Baratayuda. Prabu Duryudana membangunkan Prabu Krisna dengan mengelus-elus pahanya, hal ini menandakan bahwa dia akan mati terkena gada

${ }^{20}$ Lakon ini kemudian dikenal dengan lakon Kresna Gugah.

${ }^{21}$ Kematian begawan Bisma dalam perang bratayuda merupakan buah dari pekerjaannya ketika dia masih muda, sebelum dia menjadi seorang Resi. Ketika dia memutuskan untk menjadi seorang brahmana/ brahmacari, layaknya seorang brahmana dia tidak akan menyentuh atau bersetubuh dengan seorang wanita. Namun demikian Dewi Amba, salah satu dewi yang diboyongnya dalam suatu sayembara, terlanjur cinta kepada Dewabrata, nama muda dari resi Bisma. Dewi Amba terus mengejar Dewabrata agar mau menikahinya dan resi Bisma menolak karena komitmennya untuk menjadi seorang brahmana. Karena rasa jengkel karena dewi Amba terus menerus mengejarnya, dia menakut-nakuti dewi amba dengan senjata jemparing panah. Namun demikian anak panah tanpa sengaja malah melesat dan membunuh sang dewi. Sebelum sang Dewi naik ke Surga, dia berujar bahwa dalam peperangan besar, Resi Bisma akan mati ditangan seroang perempuan. (Purwadi, Cerita, 39). 
peperangan itu Kurawa harus mengecap kekalahan, Prabu Karna telah gugur ditangan Janaka. Prabu Salya, patih Sengkuni dan Prabu Duryudana juga gugur dalam peperangan.

\section{Tuhan yang Berperang bersama Israel dalam Peristiwa Exodus}

Setiap segi kehidupan, terjalin dengan Tuhan termasuk di dalamnya adalah peperangan, ${ }^{22}$ oleh sebab itu bangsa Israel begitu kuat mengimani bahwa Tuhan turut bersama dengan mereka dalam peperangan. Hal ini ditunjukkan melalui teks-teks yang mengandung makna peperangan di dalamnya. Lind menganggap bahwa tradisi perang atau paradigma perang dalam bangsa Israel berakar pada peristiwa keluarnya bangsa Israel dari Mesir,

Israel's understanding was rooted in miraculos intervension in its early history, espesially the miraculos experience of deliverence from egypt, which formed the fundamental paradigm for isreals' subsequent interpretation of history, the history of a minority power among the great soalitions of city state. ${ }^{23}$

Peristiwa Keluaran bisa saja dibaca dalam perpektif keberpihakan Tuhan terhadap Israel. Keberpihakan tersebut ditunjukkan dengan telah melihatnya Tuhan terhadap kesengsaraan umat dan mendengar seruan mereka yang disebabkan oleh pengerahpengerah Mesir yang begitu rupa menindas mereka. Tuhan telah peduli terhadap Israel dalam segenap kesusahan mereka. Dalam Keluaran 2:23-24, "rupa-rupanya Tuhan tidak mendengar, tidak melihat dan tidak mengambil tahu tentang orang Israel itu, Ia berlaku terhadap mereka seolah-olah Ia tuli dan buta." ${ }^{24}$ Namun kemudian yang pertama-tama Tuhan mendengar orang Israel mengerang, seolah-olah Ia dibangunkan oleh teriak minta tolong, lalu Tuhan ingat kepada perjanjiannya dengan Abraham Ishak dan Yakub, kemudian dia melihat dan mengetahui umat Israel hidup dalam ketidakadilan. ${ }^{25}$ Kesengsaraan ternyata diperhatikan oleh Tuhan, Dia mengingat perjanjiannya dengan para

\footnotetext{
${ }^{22}$ Ensiklopedi Alkitab Masa Kini, s.v. “perang” (Jakarta: Yayasan Komunikasi Bina Kasih, 1995), 238.

${ }^{23}$ Millard C. Lind, Monotheism, Power, Justice: Collected Old Testament Essays (Elkhart: IMS, 1990), 172.

${ }^{24}$ H. Rosin, Tafsir Alkitab. Kitab Keluaran 1-15:21 (Jakarta: BPK Gunung Mulia, 1994), 38.

${ }^{25}$ Ibid., 38-39.
} 
Patriakh. ${ }^{26}$ Hal ini memberikan pemahaman bahwa Tuhan tidak lupa dengan apa yang dijanjikan-Nya; Ia tidak lupa terhadap manusia yang dikasihi dan diselamatkan-Nya. ${ }^{27}$

Bentuk perhatian kepada umat Israel dilanjutkan dengan pemanggilan-Nya kepada Musa. Dalam ayat 7-12, terdapat kalimat-kalimat yang menunjukkan bagaimana perhatian Tuhan kepada umat Israel: (7) Aku telah memperhatikan dengan sungguh, Aku telah mendengar seruan mereka, Aku mengetahui penderitaan mereka, (8) Aku telah turun untuk melepaskan, (Aku) menuntun mereka keluar dari negeri itu, (9) Seruan orang Israel telah sampai kepada-Ku: juga telah Kulihat, betapa kerasnya orang mesir menindas mereka. Tuhan berniat untuk bertindak, di gunung horeb dimulainya pelaksanaan keputusan untuk menolong orang Israel. ${ }^{28}$ Keputusan-Nya ini kemudian ditindaklanjuti dengan pengutusan Musa. Pengutusan Musa merupakan suatu bentuk kepedulian, bentuk kasih Tuhan kepada umat Israel. "...Tuhan tidak hanya menjadi penonton yang tak berdaya, yang hanya bersedih. Dialah yang bertindak dalamcinta kasih dan kuasa yang berdaulat atau kesulitan yang dilihat-Nya dan atas ratapan yang didengar-Nya, sebab Dia telah mengambil sumpah perjanjian di atas pundak-Nya berkenaan dengan bangsa ini". ${ }^{29}$ Jadi jika boleh disimpulkan bahwa tindakan pengutusan Musa didasarkan pada rasa kepedulian, cinta kasih atau perhatian Tuhan kepada umat-Nya, sembari mengingat perjanjian-Nya kepada para Partiakh.

Keluaran menggambarkan Tuhan sebagai seorang pahlawan perang yang secara eksplisit disebut dalam Keluaran 15:3 ${ }^{30}$. Tuhan digambarkan sebagai sosok pahlawan perang yang berperang dengan bangsa Mesir, dan menghasilkan kekalahan terhadap bangsa itu. Tuhan sebagai pahlawan perang akan bertempur dan mengalahkan para pihak yang secara tidak sah memangku kekuasaan publik ${ }^{31}$, bahkan Tuhan mau berdarah-darah

${ }^{26}$ Brevard S. Childs, Exodus (London: SCM Press, 1974), 32. Childs lebih lanjut mengungkapkan bahya ayat ini bagian titik balik dari narasi keluaran. Narasi pertama membawa pembaca kembali kepada masa Israel ketika ditanah Mesir. Dan yang kedua adalah Kesengsaraan mereka yang diperhatikan.

${ }^{27}$ Martinus Theodorus Mawene, Perjanjian Lama \& Teologi Kontekstual (Jakarta: BPK Gunung Mulia, 2012), 176. Mengenai TUHAN yang mengingat Mawene menggunakan ayat dalam Kejadian 8:1, 9:15 dan 19:29.

${ }^{28}$ Rosin, Tafsiran, 46.

${ }^{29}$ Hywel R. Jones, Tafsir Alkitab Masa Kini 1, terj. P.S. Naipospos (Jakarta: Yayasan Komunikasi Bina Kasih, 2012), 153.

${ }^{30}$ Dalam nyanyian laut mati, Lind melihat bahwa nyanyian ini mengikuti pola dai Epik Baal. Setelah Baal mengalahkan Yam, sebuah tempat dibuat untuk dia dan dia menjadi raja. Dengan demikian, Tuhan sebagai pahlawan akan berakhir pada Tuhan yang memerintah untuk selamanya. Oleh sebab itu, prinsip peperangan dalam bangsa Israel sebenarnya tidak dapat dipisahkan dari konsep pemerintahan, yaitu teokrasi, pemerintahan oleh Tuhan sendiri (Tuhan Kingship), dimana Tuhan sebagai raja tidak memiliki paralel atau padanan dengan raja manusia.

${ }^{31}$ Walter Brueggemann, Teologi Perjanjian Lama. Kesaksiann Tangkisan Pembelaan (Maumere: Ladelero, 2009), 369. 
bagi Israel untuk menciptakan masa depan bagi Israel di luar lingkup pendindasan ${ }^{32}$. Brueggeman menjelaskan bahwa Israel memiliki kesaksian Tuhan yang sanggup membebaskan. Brueggeman juga mengungkapkan bahwa "kesaksian Tuhan sebagai pembebas menyingkapkan kemampuan dan tekad Tuhan untuk melakukan campur tangan secara tegas melawan setiap keadaan dan kekuatan yang menindas dan yang membuat orang terasing yang menghangi kehidupan yang sejahtera"33.

Kesaksian ini tentunya tidak terlepas dari metafora Tuhan sebagai sosok pahlawan perang yang membebaskan umatnya dari pendindasan. Namun demikian metafora ini juga tidak boleh kita pisahkan dari metafora-metafora yang lain. Ada kecenderungan untuk memilih salah satu metafora yang kita sukai, namun demikian tidak hanya ada satu metafora yang digunakan kepada Tuhan, dia bisa digambarkan sebagai seorang pahlawan perang namun juga dapat digambarkan sebagai inang pengasuh yang lembut ${ }^{34}$. Jadi dapat dikatakan Tuhan itu serupa dengan pahlawan perang dan serupa pula dengan gembala, namun pada ujung-ujungnya bukan gembala dan juga tidak sepenuhnya pahlawan perang, serupa dengan keduanya namun tidak sepenuhnya sama dengan salah satunya ${ }^{35}$.

\section{Baratayuda dan Exodus}

Kita dapat melihat adanya beberapa kesamaan umum antara perang Baratayuda dengan peristiwa Keluaran:

\begin{tabular}{cll}
\hline No & \multicolumn{1}{c}{ Baratayuda } & \multicolumn{1}{c}{ Keluaran } \\
\hline 1. & $\begin{array}{l}\text { Peperangan antara Pandawa dan } \\
\text { Kurawa (yang baik dan yang jahat). }\end{array}$ & $\begin{array}{l}\text { Peperangan antara Israel dan Mesir } \\
\text { (yang baik dan yang jahat). }\end{array}$ \\
\hline 2. & $\begin{array}{l}\text { Penindasan dalam bentuk pengasingan } \\
\text { Pandawa dari tempatnya, Indraprasta } \\
\text { (unsur penindasan/ ketidakadilan). }\end{array}$ & $\begin{array}{l}\text { Penindasan dalam bentuk kerja paksa } \\
\text { (unsur penindasan/ ketidakadilan). }\end{array}$ \\
\hline 3. & Keberpihakan Dewa kepada Pandawa. & Keberpihakan Tuhan kepada Israel \\
\hline 4. & $\begin{array}{l}\text { Kurawa yang ngeyel untuk memberikan } \\
\text { Indraprasta pada Pandawa. }\end{array}$ & $\begin{array}{l}\text { Firaun yang ngeyel memberikan } \\
\text { kebebasan kepada bangsa Mesir. }\end{array}$ \\
\hline 5. & $\begin{array}{l}\text { Pada akhirnya Pandawa yang } \\
\text { memenangkan perang. }\end{array}$ & $\begin{array}{l}\text { Israel (Tuhan) menang perang melawan } \\
\text { Israel. }\end{array}$ \\
\hline
\end{tabular}

Tentunya ada kesamaan dan perbedaan dalam dua narasi ini yang masih digali lebih mendalam lagi. Dalam hal ini ada beberapa pokok teologi yang menurut saya penting

\footnotetext{
${ }^{32}$ Ibid., 369.

${ }^{33}$ Ibid., 266.

${ }^{34}$ Ibid., 356.

${ }^{35}$ Ibid., 356-357.
} 
untuk diperhatikan dalam keduanya, yang bisa digunakan untuk sebuah refleksi teologis menyikapi realita peperangan pada masa moderen.

\section{Keberpihakan Ilahi terhadap yang Tertindas dalam Peperangan}

Dalam perang besar Baratayuda, dewata ternyata berpihak kepada Pandawa. Keberpikahan para Dewa ini ditunjukan dengan bergabungnya Prabu Kresna kepada Pandawa. Perlu kita ingat bahwa Prabu Krena adalah titisan dewa Wisnu. Bahkan pada lakon Kresna Duta pada waktu Prabu Krsena dijadikan sebagai utusan, Batara Narada dan tiga Batara lain menjadi saksi yang ada bersama dengan Kresna. Artinya dalam cerita tersebut dewa telah berpihak kepada Pandawa. Mengapa? Tentunya karena keadilan dan kebenaran. Pandawa telah mengalami ketidakadilan, bahkan sejak dari naik tahtanya Destrarastra sampai dengan pengasingan mereka. Juga sosok Kurawa yang merupakan perwakilan dari sosok jahat/ antagonis, tentunya membuat para dewa berpihak kepada Pandawa. ${ }^{36}$ Keberpihakan para dewa ini lebih lanjut dituliskan dalam kitab Jipasta yang melukiskan jalannya peperangan Baratayuda, artinya dewa sendiri sudah merancangkan kemenangan pada pihak pandawa.

Hal yang serupa kita dapati dengan Tuhan dalam peristiwa pembebasan. Israel telah mengalami ketertindasan, dan Tuhan telah mendengar, melihat dan memperhatikan ketertindasan mereka. Oleh sebab itu Tuhan turun tangan dan menyelamatkan umatnya, bahkan telah memberikan kemenangan kepada umat Israel. C. Barth mengungkapkan bahwa bukan orang-orang Mesir secara komunal yang jahat tetapi Firaun. Berulang kali dikatakan bahwa "Firaun keras hati", "tidak mau mendengar" dan "tidak mau melunakkan hatinya". Dengan yang jahat sekali-kali bukan orang-orang Mesir, tetapi rezim yang pada waktu itu berkuasa. Oleh sebab itu Tuhan telah turun tangan dan berperang sekaligus berpihak kepada Israel yang telah ditindas dan tidak memperoleh keadilan di Mesir pada rezim Firaun.

\section{Perang, bukan untuk Pamer Kekuatan, tapi Membebaskan dari Ketertindasan}

Baik perang Baratayuda maupun perang Tuhan melawan bangsa Mesir memiliki tujuan keadilan: Baratayuda terjadi karena Pandawa menuntut keadilan yang telah

\footnotetext{
${ }^{36}$ Namun kita perlu memperhatikan juga bahwa ada dewa yang tidak berpihak kepada pandawa
} yaitu Bathari Durga. 
dirampas oleh Kurawa ${ }^{37}$ dengan cara yang amat licik. Demikian halnya dengan Israel, di tanah Mesir mereka telah mengalami ketidakadilan dan penindasan, mereka menjadi budak ditanah Mesir ${ }^{38}$. Tuhan berperang untuk bangsa Israel demi keadilan, hal ini menunjukkan kepedulian Tuhan bukan hanya secara individual maupun secara koletif. "Ia memasuki hidup sehari-hari umat-Nya dan memberikan keadilan kepada mereka yang berseru kepada-Nya. Ia membebaskan mereka dari keadaan yang penuh dengan penderitaan, dari ketertindasan, dari ketidakadilan dan sebagainya"39.

\section{Perang untuk Memusnahkan yang Jahat}

Harus diakui bahwa di dalam seni pewayangan penuh dengan dualisme, antara yang baik dan jahat. Tokoh baik pada akhirnya akan menerima kemenangan, meskipun pada awal atau pertengahan cerita harus menerima kekalahan ${ }^{40}$. Konsep dualisme yang demikian memang harus dipertanyakan kembali dalam Keluaran, artinya apakah benarbenar pertentangan antara Israel dan Mesir, apakah Israel bisa disebut sebagai pihak yang baik dan dengan demikian Mesir mewakili pihak yang jahat. Sebelum menarik kesimpulan itu ada baiknya memperhatikan Ulangan 7:7-8 dan 9:5 di mana upaya penyelamatan itu (dan yang kemudian adalah pendudukan tanah Kanaan) guna menepati janji-Nya yang telah diberkian kepada para bapa leluhur. Dengan demikian dualisme yang ada bukan antara Israel dan Mesir, melainkan antara Tuhan dan Mesir, Tuhan yang ingin memenuhi janji-Nya kepada nenek moyang bangsa Israel dengan jalan membebaskan Israel dari perbudakan Mesir.

\section{Kesimpulan}

Tuhan sebagai pahlawan perang telah memilih keberpihakannya kepada Israel. Tentunya hal ini adalah bahasa iman dari umat Israel bahwa Tuhan telah berada dipihak mereka. Tuhan yang berpihak kepada Israel adalah Dia yang berpihak kepada yang lemah, tertindas dan berpegang kepada kebenaran. Dalam beberapa kasus, Tuhan juga tidak berpihak kepada Israel ketika bangsa itu tidak berbuat kebenaran, dan justru mendatangkan hukuman atas Israel. Dengan demikian sangatlah jelas bahwa melalui peristiwa Exodus

\footnotetext{
${ }^{37}$ Prabu Duryudana tidak mau menepati janji untuk mengembalikan Indraprasta/ Amarta kepada Pandawa (Purwadi. Cerita... hal 7)

${ }^{38}$ Keluaran 3:7.

${ }^{39}$ Martinus Theodorus Mawene, Perjanjian Lama \& Teologi Kontekstual (Jakarta: BPK Gunung Mulia, 2012), 49.

${ }^{40}$ Hal ini memunculkan ungkapan dalam masyarakat jawa: lakon menang keri. Lakon akan menang terakhir.
} 
semakin menguatkan bahwa Mesir atau menurut C. Barth adalah Firaun dan rezimnya merupakan bangsa yang jahat, atau setidaknya secara naratif memainkan peran antagonis. Tuhan dengan lengannya yang kuat telah membebaskan bangsa Israel dari tangan orang Mesir!

Apa yang terjadi dalam peristiwa perang Bratayuda Jayabinangun juga dapat dilihat dalam kacamata iman umat Israel yang menganggap bahwa Tuhan telah berpihak pada mereka. Para Dewa, secara khusus Prabu Kresna sebagai dewa Wisnu telah menyatakan keberpihakannya kepada para Pandawa. Sejak peristiwa Kresna Gugah dia menyatakan bahwa dalam perang besar itu dia akan berpihak kepada Pandawa. Keberpihakannya sebagai representasi dari keberpihakan para dewa kepada Pandawa tentunya tidak hanya dilihat dari satu lakon itu saja, tetapi sejak dari awal dan secara keseluruhan. Secara umum, Pandawa telah ada pada pihak kebenaran, Pandawa memegang teguh kebenaran dan selalu menjunjung keadilan. Sebagai pihak yang membela kebenaran, Pandawa juga telah menerima berbagai perlakuan tidak baik dari para Kurawa. Mulai dari tanah dan kerajaan yang dirampas sampai dengan berbagai upaya untuk memusnahkan Pandawa. Melalui peristiwa perang besar Baratayuda telah membuktikan segalanya.

Para Dewa telah secara tepat perpihak dan bahkan membela para Pandawa, seperti hanya Tuhan yang membela Israel, yaitu membela kepada yang tertindas dan membela kepada yang benar. Pandawa dalam beberapa hal juga sama seperti bangsa Israel yang mengalami penindasan dan berada pada pihak yang benar, meskipun ada hal-hal yang tentunya harus digali lebih lanjut lagi. Sementara itu Kurawa sebagai pihak antagonis telah seperti bangsa Mesir yang jahat dan menindas bangsa Israel.

Dalam hal ini ada nilai-nilai yang secara umum dapat digunakan untuk menyikapi berbagai peperangan yang sedang berkecambuk di beberapa wilayah, misalnya di Timur Tengah. Pertama, dalam peperangan Tuhan akan selalu berpihak kepada yang benar dan yang tertindas. Siapakah yang tertindas dalam peperangan? Seperti kata pepatah yang mengatakan "gajah bertarung dengan gajah, pelanduk mati di tengah-tengah", rakyatlah yang menjadi korban dari sebuah peperangan. Sudah banyak sekali korban jiwa dari warga sipil yang berjatuhan akibat konflik-konflik di wilayah timur tengah. Secara teologis, Tuhan-lah yang berpihak pada rakyat yang tertindas akibat perang. Tuhan melihat penderitaan dan ketertindasan mereka seperti halnya Tuhan melihat penderitaan Israel dan dewa yang melihat penderitaan Pandawa. Kedua, peperangan adalah upaya untuk membebaskan dan mengalahkan kejahatan. Kejahatan dan penindasan yang akut dapat diselesaikan melalui peperangan, hal ini misalnya terjadi pada peperangan-peperangan 
yang bertujuan untuk kemerdekaan (misalnya perang Diponegoro). Oleh sebab itu, jika bukan karena alasan ini, harusnya tidak boleh ada peperangan, karena kemerdekaan adalah hak dari semua bangsa!

\section{Kepustakaan}

Brueggemann, Walter. Teologi Perjanjian Lama. Kesaksiann Tangkisan Pembelaan. Maumere: Ladelero, 2009.

Budiarti, Endah. "Lakon Baratayuda Versi Klaten: Kajian Struktur Naratif". Resital: Jurnal Seni Pertunjukan 13, no. 2 (Desember 2012): 166.

Childs, Brevard S. Exodus. London: SCM Press, 1974.

Jones, Hywel R. Tafsir Alkitab Masa Kini 1, terj. P.S. Naipospos. Jakarta: Yayasan Komunikasi Bina Kasih, 2012.

Lind, Millard C. Monotheism, Power, Justice: Collected Old Testament Essays. Elkhart: IMS, 1990.

Mawene, Martinus Theodorus. Perjanjian Lama \& Teologi Kontekstual. Jakarta: BPK Gunung Mulia, 2012.

Purwadi. Serat Bharatayuda. Surakarta: Cendrawasih, 2014.

Falsafah Militer Jawa. Praktik kemiliteran ala kerajaan-kerajaan Jawa. Bantul: Aksara, 2015.

Seni Pedhalangan Wayang Purwa. Jakarta, 2017.

Rosin, H. Tafsir Alkitab. Kitab Keluaran 1-15:21. Jakarta: BPK Gunung Mulia, 1994.

Tanpa nama. Ensiklopedi Alkitab Masa Kini, s.v. "perang”. Jakarta: Yayasan Komunikasi Bina Kasih, 1995.

Winter, Karel Fredrik. Serat Bratayuda. Jakarta: Departemen Pendidikan dan kebudayaan, 1980. 